\title{
Urban waste disposal explains the distribution of Black Vultures (Coragyps atratus) in an Amazonian metropolis: management implications for birdstrikes and urban planning
}

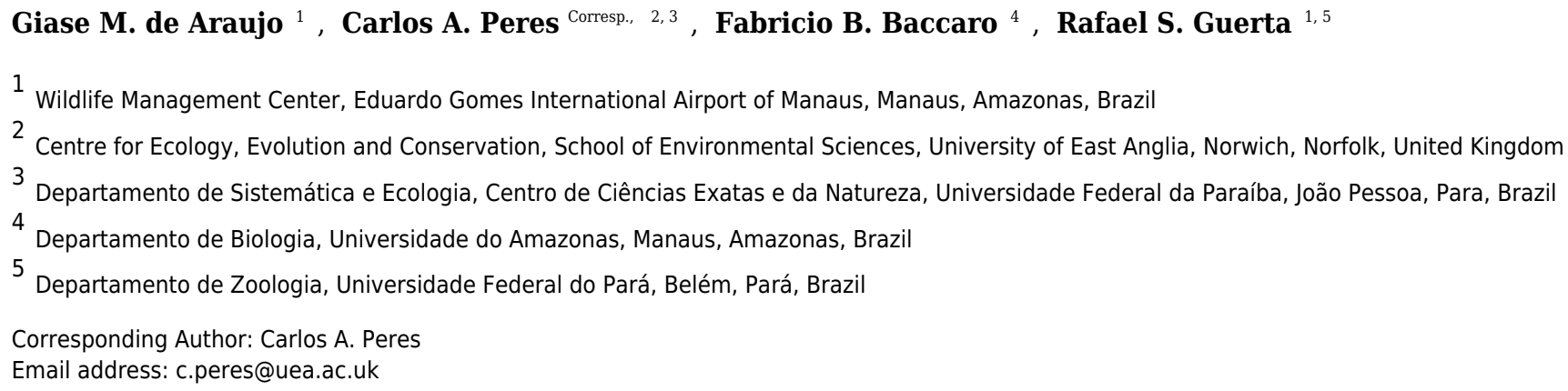

Collision rates between aircraft and birds have been rising worldwide. The increases in both air traffic and population sizes of large-bodied birds in cities lacking urban planning result in human-wildlife conflicts, economic loss and even lethal casualties. Black Vultures (Coragyps atratus) represent the most hazardous bird to Brazilian civil and military aviation on the basis of their flight behavior, body mass and consequently physical damage to aircraft following collisions. This study investigated how storage apparatus and type of organic residue discarded in public street markets modulate the spatial distribution and abundance of urban Black Vultures in the largest city in the Amazon (Manaus, Brazil). We estimated Black Vulture abundance in relation to the type of solid human waste (animal or plant), the type of waste storage containers and market sizes in terms of the number of vendor stalls at 20 public markets. We also visually quantified the abundance of Black Vultures in urban markets in relation to air traffic. Our results suggest that urban solid waste storage procedures currently used (or the lack thereof) are related to the occurrence and abundance of Black Vultures. Moreover, storage type and the proportion of animal protein (red meat and fish) within rubbish bins directly affects foraging aggregations in vultures. We recommend that policymakers should invest more efforts in building larger and more resistant closable waste containers to avoid organic solid waste exposure. We also identified five outdoor markets as urgent priorities to improve waste disposal. Finally, our waste management guidelines would not only reduce aviation collision risks but also benefit human health and well-being in most cities. 
1 Urban waste disposal explains the distribution of Black Vultures (Coragyps atratus) in an 2 Amazonian metropolis: management implications for birdstrikes and urban planning

3

4 5
Giase Melo de Araujo ${ }^{1}$, Carlos A. Peres ${ }^{2,3}$, Fabricio Beggiato Baccaro ${ }^{4} \&$ Rafael Soave Guerta ${ }^{1,5}$

${ }^{1}$ Wildlife Management Center, Eduardo Gomes International Airport of Manaus, Manaus, AM, Brazil.

${ }^{2}$ Centre for Ecology, Evolution and Conservation, School of Environmental Sciences, University of East Anglia, Norwich, Norfolk, United Kingdom

${ }^{3}$ Departamento de Sistemática e Ecologia, Centro de Ciências Exatas e da Natureza, Universidade Federal da Paraíba, João Pessoa, PB, Brazil

${ }^{4}$ Departamento de Biologia, Universidade Federal do Amazonas, Manaus, AM, Brazil.

${ }^{5}$ Departamento de Zoologia, Universidade Federal do Pará, Belém, PA, Brazil.

Corresponding Author:

Carlos A. Peres

Email address: C.Peres@uea.ac.uk 


\section{Abstract}

48 Collision rates between aircraft and birds have been rising worldwide. The increases in both air traffic and population sizes of large-bodied birds in cities lacking urban planning result in humanwildlife conflicts, economic loss and even lethal casualties. Black Vultures (Coragyps atratus) represent the most hazardous bird to Brazilian civil and military aviation on the basis of their flight behavior, body mass and consequently physical damage to aircraft following collisions. This study investigated how storage apparatus and type of organic residue discarded in public street markets modulate the spatial distribution and abundance of urban Black Vultures in the largest city in the Amazon (Manaus, Brazil). We estimated Black Vulture abundance in relation to the type of solid human waste (animal or plant), the type of waste storage containers and market sizes in terms of the number of vendor stalls at 20 public markets. We also visually quantified the abundance of Black Vultures in urban markets in relation to air traffic. Our results suggest that urban solid waste storage procedures currently used (or the lack thereof) are related to the occurrence and abundance of Black Vultures. Moreover, storage type and the proportion of animal protein (red meat and fish) within rubbish bins directly affects foraging aggregations in vultures. We recommend that policymakers should invest more efforts in building larger and more resistant closable waste containers to avoid organic solid waste exposure. We also identified five outdoor markets as urgent priorities to improve waste disposal. Finally, our waste management guidelines would not only reduce aviation collision risks but also benefit human health and well-being in most cities.

\section{Introduction}

Collision rates between aircraft and birds, widely referred to as birdstrikes, have been escalating worldwide (Allan, 2000; Dolbeer, 2011, Dolbeer et al., 2016). Some of the known reasons for such increases include both the burgeoning aviation industry leading to much higher air traffic (Mendonça, 2009) and increases in bird population sizes in cities lacking urban planning (Bastos, 2000; Dolbeer \& Eschenfelder, 2003; Dolbeer \& Seubert, 2009). In some cases, birdstrikes can result in severe damage to aircrafts, less frequently leading to deaths of both crew and passengers (Richardson \& West, 2000; Allan, 2002; Thorpe, 2003; Thorpe, 2005; Thorpe, 2016). As a result, bird population monitoring and wildlife control measures have increasingly become a glaring concern for aviation agencies (BRASIL, 2012; ANAC, 2014; AAA, 2016). 
Although birds are the main taxonomic group involved in aircraft accidents (Cleary,

78

79

80

81

82 Dolbeer, Wright, 2005), the degree to which any specific bird species can be considered a hazard to aviation depends on the body size, habitat and behavior of individual bird populations (Dolbeer et al., 2000; DeVault et al., 2011). In Brazil, most birdstrike collisions result from large-bodied urban raptors (e.g. vultures, hawks and falcons) belonging to the families Cathartidae, Accipitridae, and Falconidae (CENIPA, 2016). Further, over the last three decades, vultures (Cathartidae, Lafresnaye, 1839) were ranked as the most hazardous birds to Brazilian urban aviation on the basis of on their flight behavior, large size and consequently physical damage to aircrafts following collisions (Serrano et al., 2005; Novaes \& Alvarez, 2010; Novaes \& Alvarez, 2014; CENIPA, 2016). For instance, a single collision involving two Turkey Vultures (Cathartes aura) in 2012 near the Manaus International Airport (MAO) resulted in engine failure and financial losses of $\sim$ US\$ 750,000 (CENIPA, 2017).

The spatial distribution of birds in urban environments is related to several factors including the presence of food resources and shelters (roosting sites) as, for example, in Black Vultures (Coragyps atratus) (Novaes \& Cintra, 2013). It is therefore possible to reduce birdstrike probability by simply modifying and monitoring the environment surrounding airports and rendering them less attractive to birds as foraging habitats (Blackwell et al., 2009; Martin et al., 2011). As the majority of birdstrikes occur both within and very near airport landing and take-off areas (Dolbeer 2006; Dolbeer et al., 2016), it is crucial to identify (i) what urban features are attractive to birds, and (ii) which species are most often directly related to collisions, both of which are crucial to urban planners to improve aviation safety.

The Black Vulture is an ubiquitous and often abundant species in Brazilian cities (Sick, 1997). They are easily identified by the absence of head and neck feathers, which may assist with hygiene after eating, since their diet is frequently comprised of decomposing animal carcasses and other organic human waste (DeVault et al., 2016). Black Vultures are highly successful opportunist scavengers and exhibit gregarious behavior, actively using manmade structures to both forage and roost (Novaes \& Cintra, 2013). They also frequently take advantage of wind thermals to gain flight elevation and save energetic expenditure while soaring (Freire et al., 2015).

In this study, we examine how the storage apparatus and type of organic residue discarded in public street markets influence the distribution and abundance of urban Black Vultures, the main bird species involved in birdstrike risk at large Amazonian cities. During an observational study, 
108 we estimated Black Vulture abundance in relation to the type of solid human waste (animal or 109 plant), the type of waste storage containers and market sizes in terms of the number of vendor 110 stalls at 20 public outdoor markets in Manaus. We also visual examined the abundance of Black

111 Vultures in urban markets in relation to the main hubs of air traffic. We further recommend simple 112 management and storage measures to control the local abundance of this species. This low-cost set 113 of suggested actions can be rapidly implemented to reduce the probability of avian collisions with 114 aircraft, and they are also expected to work in other cities facing similar problems.

116 Materials \& Methods

\section{Study Area}

118 Fieldwork was conducted in both urban and suburban areas of Manaus $\left(03^{\circ} 80^{\prime} \mathrm{S}, 60^{\circ} 01^{\prime} \mathrm{W}\right)$,

119 in Central Brazil Amazonia. Manaus is the largest and most populated Amazonian city, spans an 120 area of $377.4 \mathrm{~km}^{2}$ and is surrounded by rainforest to the north and east, and the Negro and Amazon 121 rivers to the south and west. Mean annual temperature in Manaus is $30^{\circ} \mathrm{C}$ and the climate is 122 classified as tropical humid (Loureiro, Carlos \& Lamberts, 2001). Mean annual precipitation is $1232,195 \mathrm{~mm}$ with a rainy season between December and May, and a dry season between June and 124 November (Loureiro, Carlos \& Lamberts, 2001). The city has grown rapidly since it became a 125 duty-free port and hub of the Brazilian manufacture industry, doubling its population size in recent 126 decades. In 1991, Manaus had approximately 1 million inhabitants, whereas the latest census 127 (2017) recorded a population size of 2.13 million (IBGE, 2017), representing a 113\% increase over 128 three decades.

\section{Bird Counts}

Manaus has 35 open-air markets registered by the urban administration as regular legal markets (SUBSEMPAB, 2018). These public markets are distributed throughout the entire city 133 and are used to commercialize several types of local products including red meat, fish, fruits and 134 vegetables. We monitored 20 open-air public markets distributed across the main city 135 neighborhood sectors (or bairros). Our aim was to estimate black vulture population size over the 136 entire city area. Our sampling design covered $\sim 60 \%$ of all open-air markets in Manaus. This wide 137 variety of markets allowed us to examine different forms of organic waste storage. Monitoring 138 occurred between 18 November 2014 and 20 February 2015. Sampling consisted of five visits to 
139 each street market from $09: 00 \mathrm{~h}$ to $16: 00 \mathrm{~h}$, the time interval corresponding to the peak activity 140 period for Black Vultures (e.g. Avery et al., 2011; Novaes \& Cintra, 2015). Each visit lasted

141 between 10 and $15 \mathrm{~min}$ and was conducted by one observer (G.M.A.) in two steps. First the 142 observer inspected the entire area of the markets in order to locate and count all individual vultures 143 present in a vehicle driven by a motorist at a constant slow velocity of $<20 \mathrm{~km} / \mathrm{h}$. The markets 144 were located along linear streets and in most markets the garbage disposal was concentrated in a 145 single main location per market, thereby facilitating vulture counts. After carefully inspecting the 146 entire market area, the observer left the vehicle to count from a reasonably short distance (beyond 147 escape responses) all individuals that were on the ground. The detection radius was $\sim 30 \mathrm{~m}$. 148 Subsequently, all vultures soaring overhead and above the market were also counted. To avoid 149 double counting, only one observer recorded local vulture abundance. At each visit, the abundance 150 and location of all Black Vultures were recorded, as well as their main behavioral activity pattern 151 (i.e. resting, flying, foraging, and social interactions).

Waste Storage

A classification of waste type (red meat, fish, fruits and vegetables) was assigned to any exposed organic waste observed during each bird census period using a visual estimation method. A standardized estimate of the proportion of each waste type was conducted by the same observer (G.M.A.) at all street markets. Waste storage was categorized as "without container", whenever any given market lacked any type of rubbish bin facilities or specific storage containers, thereby resulting in waste being discarded haphazardly at open-air sites. Markets containing rubbish bin facilities were classed into two types: "small house"' and "container" markets (Figure 1).

"Small house" rubbish bins were of a rectangular shape, made of brick masonry with a door entrance (but often lacking a door), and were used to protect any solid waste from wind and rain. Those rubbish bins were made by local vendors from each street market (Figure 1A and 1B). "Container" rubbish bins, on the other hand, consisted of metal box frames covered by a heavy protective lid. The containers usually provided effective waste protection, but in all cases the metal lid was removed or remained open at all times in order to facilitate waste disposal (Figure 1C-1F). Although these two types of rubbish containers were the most common in street markets in Manaus and were cleaned on a daily basis by rubbish collectors hired by the public waste management 
169 service, they lacked any regular repair or maintenance service.

170

171 Historical Birdstrike Records and Sighting Reports

172 All collisions events with vertebrate species (bird, bats, terrestrial reptiles and mammals 173 larger than $1 \mathrm{~kg}$ ) found or observed within an airport operation area are reported to the federal 174 wildlife strike management agency (Aeronautical Accidents Investigation and Prevention Center, 175 hereafter, CENIPA) together with details describing the event and the species, according to law 176 12.725/2012 (CENIPA, 2017). Furthermore, a resolution (No. 466/2015) from the National

177 Environmental Council issued the first risk assessment methodology applied to wildlife within the 178 aviation sector context. This resolution defines and categorizes each incident according to the 179 following details: (i) crewmembers or ground airport operators observes a collision event; (ii) 180 maintenance personnel identifies evidence or damage caused by the collision with the aircraft; and 181 (iii) animal remains are found within $50 \mathrm{~m}$ of runway or taxiway boundaries, or within $300 \mathrm{~m}$ from 182 a runway threshold, unless qualified technical personnel identifies the cause of death of the animal 183 as unrelated to a collision event. The resolution also defines air strikes as event occurring generally 184 outside aerodrome boundaries, in one of the following flight phases: take-off, climb, cruise, low185 level navigation, descent, approach (landing) and during in-transit inspections. Additional details 186 can be found at the Brazilian Annual Wildlife Strike Summaries available at the CENIPA website 187 (http://www2.fab.mil.br/cenipa/index.php/prevencao/risco-da-fauna). We extracted information 188 on birdstrikes and number of aircraft movements for the two main airports of Manaus on the basis 189 of systematic records spanning three consecutive years (CENIPA annual reports: 2013-2015). To 190 provide a comparative perspective, all data and collision analyses are conventionally reported for 191 each set of 10,000 aircraft movements (flights). We used this information together with airport and 192 street markets spatial data to understand spatio-temporal patterns of birdstrikes in Manaus.

193

\section{Data Analysis}

Since our main response variable consists of discrete count data based on five visits to each market, we used generalized linear mixed models (GLMM) with a Poisson distribution of residuals. The number of vultures observed during each market survey was our dependent variable 
198 and market size (estimated by the number of red meat/fish boxes in the market), proportion of solid 199 animal waste (red meat and fish/total waste), and presence/absence of rubbish bins were the 200 predictor variables in the model. We build separate models to explain vulture abundance on the 201 ground or flying, as well as total abundance. We counted only vultures flying at relatively low 202 heights in the immediate proximity to markets, so that individuals soaring in thermals at high 203 elevations were excluded. To account for our spatially nested design, we included market as a 204 random variable in the models. To validate the model fit, we compared the Akaike's Information 205 Criterion (AIC) of the GLMM with the respective AIC of the null model (intercept only + random 206 variable). The full GLMM model was selected, when the AIC difference between the full and null model was greater than 2 (Burnham \& Anderson, 2002). We report the marginal and the conditional $\mathrm{R}^{2}$ for the GLMM model. Marginal $\mathrm{R}^{2}$ provides the variation explained by the fixed variables only, while the conditional $\mathrm{R}^{2}$ gives the variation explained by the fixed and random effects in the model (Nakagawa and Schielzeth, 2013). We also performed residual analysis to verify the adequacy of model predictions. We used partial graphs to present the GLMM results in simple 2D plots. The graph shows expected values of the dependent variable and expected values

213 of the target independent variable if all other independent variables in the analysis were maintained 214 at their median values (Breheny \& Burchett, 2017). All analyses were carried out in R 3.2.3 (R 215 Core Team, 2018).

To define the order of priority of street markets related to any possible Black Vulture

217 population control and waste storage management measures, with a view of reducing the 218 probability of birdstrikes, we performed two procedures. First, we superimposed street market 219 locations and the numeric abundance of vultures found at each market with the mainstream aircraft 220 routes within the entire airspace of the city of Manaus. The vulture abundance was scaled to the 221 percentage of animal matter in waste residues at different markets. Manaus has three aerodromes, 222 two of which serving high daily traffic of both passengers and cargo: Eduardo Gomes International 223 Airport of Manaus (ICAO: SBEG), Ponta Pelada Air Force Base (SBMN), and Flores Airport 224 (SWFN). As a private owner operates the much smaller Flores Airport, data on birdstrike and 225 aircraft movements are unavailable. However, the SWFN airport is now used only by small single226 engine airplanes and hosts fewer flights on a daily basis compared to the other two aerodromes. 227 Therefore, our analysis was primarily restricted to the SBEG and SBMN aerodromes, which 228 collectively hosted 158,223 flights over the 3-year study period. Second, we created a composite 
229 index (DI) of distance to the nearest airports by dividing the airport size (mean number of aircraft

230 flights per year) by the square-root of the linear (vulture flight) distance from each market to that

231 airport. We then merged the information about airport distance with the abundance of Black

232 Vultures of individual surveys/visits, to create a rank of priority for Black Vulture population

233 control.

234

235 Results

236 Average Black Vulture abundance varied considerably across the 20 urban markets

237 surveyed during the sampling period (Table 1). The absence of vultures was detected in half of the

238 study markets, whereas at another 10 street markets the average abundance varied from 28 at Feira

239 do Walter Rayol to 810 individuals at Feira da Panair $(\mathrm{sd}=48.40)$. Two vulture concentration

240 zones could be clearly detected in Manaus, and these are located in the extreme north portion of

241 urban area (coinciding with three outdoor street markets) and the main fishing port of the city

242 located near the downtown commercial area, where fish discards are common (Figure 2).

243 The full GLMM models provided a better fit compared to the respective null model (total

244 abundance $\triangle \mathrm{AIC}=14.25$, abundance on the ground $\triangle \mathrm{AIC}=14.55$ and abundance of flying 245 vultures $\triangle \mathrm{AIC}=2.07)$. The models that included vultures that were either perched or on the ground

246 provided a much better fit, compared with the model based solely on flying Black Vultures (Table

247 2). The fixed variables explained $\sim 63 \%$ of the variation in total vulture abundance and those on

248 the ground, but a reasonable part of the variation in Black Vulture abundance were also associated

249 with idiosyncrasies of each market (Conditional $\mathrm{R}^{2} \approx 0.88$ in both models). The presence or

250 absence of adequate rubbish bins and the proportion of animal protein (i.e. red meat and/or fish)

251 available in the solid waste discarded within each street market were strongly positively related

252 with the abundance of Black Vultures in both models (Table 2). Market size in terms of the number

253 of vendor stalls, which may be used as a proxy for amount of waste discarded was, however,

254 unrelated with the abundance of Black Vultures (Table 2). The abundance of flying Black Vultures

255 was more related to the size of the market, than to the presence/absence of rubbish bins and the

256 proportion of animal waste. However, the model explained only $\sim 16 \%$ of the abundance of vultures

257 in flight (Table 2). This indicates that the number of Black Vultures scales similarly to food

258 availability in markets with and without adequate rubbish bin facilities, where waste is discarded 
259 haphazardly, but that disposing of organic rubbish into bins decreased vulture abundance by $\sim 25 \%$

260 (Figure 3A and 3B). The effect of rubbish bin use (either a container or a small house) was

261 apparently equivalent even when container bins lacked lids or other means of effective cover.

262 The vast majority of collisions between birds and aircraft in Manaus occurred during take-

263 off, approach and landing flight maneuvers (amounting to $73 \%$ of all 101 strikes recorded during

264 the three years of CENIPA monitoring). Comparing the two Manaus airports, the largest airport

265 (Eduardo Gomes International Airport) exhibited the highest number of reported animal collisions,

266 although the rate of collisions (per aircraft flight) was higher at the Ponta Pelada Air Force Base

267 (Table 3). This result can be explained by the spatial location of some street markets within the

268 city. Only the fairly small street market of Feira da Cidade Nova is situated very near the main

269 flight paths for either approach or take-off aircraft routes from the Eduardo Gomes International

270 Airport and there were no records of Black Vultures at this market during the monitoring period

271 (Figure 2). On the other hand, four street markets containing large numbers of vultures (Feira da

272 Panair, Feira da Manaus Moderna, Mercado Walter Rayol, and Feira da Ceasa) are situated very

273 close to the approach and take-off paths of military aircraft using the Ponta Pelada Air Force Base

274 (Figures 2 and 4). In total, we recorded 1184 vulture sightings during our surveys at those four

275 street markets combined, which represented $58.9 \%$ of all vultures sighted across all 20 street

276 markets surveyed.

277

278 Discussion

279 Overall, it is evident that the waste storage system in urban street markets in Manaus and many 280 other Amazonian cities is inadequate. For example, 40\% of all monitored street markets lacked 281 any waste storage facilities. Our results indicate that the procedures currently used (or the lack 282 thereof) to store solid organic waste are clearly related to the occurrence and abundance of Black 283 Vultures in the largest Amazonian city. Further, our results suggest that waste storage 284 infrastructure and the proportion of animal protein waste discarded into rubbish bins are direct 285 drivers of the main foraging area for urban vultures. Larger numbers of vultures were consistently 286 found at sites lacking storage facilities. In particular, we note that just the presence of a rubbish 287 bin, even if it lacks proper protective cover, was enough to prevent large vulture aggregations. 288 Also, the number of vultures recorded within street markets was related to the proportion of fresh 
289

290

291

292

293

294

295

296

297

298

299

300

301

302

303

304

305

306

307

308

309

310

311

312

313

314

315

316

317

318

319

and/or decomposing animal waste available. In addition to affecting vulture occurrence, which induces higher probabilities of birdstrike collisions, poorly managed organic waste can lead to a series of detrimental environmental and epidemiological consequences, including accumulation of microbial pathogens, proliferation of disease vectors, and both soil and water contamination (Moore et al., 2003; Penrose et al., 2010).

The availability and accessibility to food resource are known as key determinant factors in shaping the habitat use and spatial distribution of cathartids (Jones, 2005, Novaes \& Cintra, 2015). Also, the total amount of food resources available, which is a key attractant to vultures, is one of the main ecological factors that affect the fine-scale spatial distribution of vultures (Permalee, 1954; DeVault et al., 2005; Novaes \& Alvarez, 2010; Novaes \& Cintra, 2013). Black Vultures use vision as the main sensory mechanism to find food resources (Houston 1986), being able to detect food sources within a 90-km radius (Novaes \& Cintra 2015). Our results suggests that Black Vultures may locate the markets during low height flying based on market size, but further select and forages in markets with higher proportion of animal waste. Our results therefore corroborate previous evidence in showing a relationship between animal solid waste availability and local abundance of Black Vultures in large metropolitan areas where food waste is inadequately managed and discarded at open-air sites.

Organic waste made available in urban street markets is clearly a critical food source for Black Vultures. Consequently, the main population control strategy for this species is to eliminate or minimize the availability of organic waste produced every day by several human activities. Our results suggest that, given a lack of financial or human resources to deal with waste management properly, decision makers should prioritize actions targeting the treatment and management of waste of animal origin. Simple management protocols, such as disposing of any waste into small container bins, are probably sufficient to be highly effective. Furthermore, environmental education campaigns focused on market vendors should be implemented in order to increase their general awareness that waste accumulation can result in direct and indirect negative effects on both human health and aviation safety (Bastos, 2000; Araujo et al., 2015). During our visits to the street markets, we noticed that even in markets with rubbish containers, local vendors still throw away organic solid waste on the street around containers. In fact, most street markets in Manaus exhibit extremely poor hygienic conditions in terms of organic waste scattered across neighboring streets. In addition, many rubbish containers present in some markets lacked proper cover. Therefore, solid 
320 waste stored within containers lacking a lid, remains available and can be easily found by vultures.

321 Black Vulture relies primarily on vision to detect and locate food resources (Coleman \& Fraser,

322 1987; Lisney et al., 2013). In street markets without a rubbish bin, any organic waste is more

323 exposed and available to urban necrophages (including vultures, rats and feral dogs and cats)

324 compared to markets using containers, thereby attracting more scavengers even if a smaller amount

325 of organic waste is disposed. Likewise, even when waste was stored inappropriately into open

326 containers lacking adequate cover was apparently enough to prevent large Black Vulture

327 aggregations in small markets producing less organic waste.

328 Only $10 \%(2 / 20)$ of all street markets in our study area provided proper waste storage 'small

329 housing' facilities that were inaccessible to urban scavengers. The lack of adequate infrastructure

330 and efficient waste collecting services fuel a larger vulture population, and consequently inflate

331 birdstrike probability risk in any large urban center in the tropics. Therefore, it is extremely

332 important that policymakers invest more efforts in building larger and more resistant waste

333 containers to avoid disease proliferation and organic pollution. In a financially restricted context,

334 however, five street markets should be prioritized — Feira Cidade Nova, Feira da Panair, Feira da

335 Manaus Moderna, Mercado Walter Rayol, and Feira do Ceasa - as they are located near take-off

336 and landing routes of the two most important Manaus airports. Furthermore, intensive campaigns

337 towards improving environmental awareness and changing local behavior and attitudes towards

338 correctly storing market organic waste are complementary strategies. Finally, installation of

339 adequately covered containers combined with more regular waste collecting services represent

340 relatively inexpensive and easy alternatives to control Black Vulture hyper-abundance in large

341 Amazonian cities like Manaus, as well as reducing the risk of birdstrikes.

342

\section{Conclusion}

344 The mismanagement of human waste derived from outdoor markets in the Amazon's largest city 345 induces the occurrence and local abundance of highly mobile urban scavengers, such as Black

346 Vultures, thereby overinflating the risk of aviation accidents. Simple and low-cost measures to

347 enhance waste disposal can reduce the size of local aggregations of avian scavengers, not to

348 mention other urban ecosystem benefits in terms of urban planning, service provision and

349 sanitation. Although urban waste disposal explains the spatial distribution of Black Vultures in 
350 large metropolitan areas such as Manaus, an efficiently adequate and frequent solid waste

351 collecting service would not be enough to effectively control and reduce vulture populations in the

352 median term. The amount of organic solid waste discarded, subsequently becoming readily

353 available, provides ample trophic subsidies to the resident Black Vulture population in Amazonian

354 towns and cities. An appropriate waste management protocol would only suppress urban scavenger

355 populations if this is executed as part of a long-term policy taking into account multiple social

356 agents linked to both waste production and management.

357

358 Acknowledgements

359 We would to thank Weber G. Novaes for his crucial role in overall project design and development.

360 We also thank Anderson Moreira da Silva and Diego Ribeiro Lima for their competent field 361 assistance. Giase M. de Araujo thanks to Rosangela Melo de Araujo e Valdir Silva de Araujo for

362 all the support. We are very grateful to all the wildlife management team from International Airport

363 of Manaus Eduardo Gomes for their useful help during fieldwork and the administrative support.

364 Finally, we thank the INFRAERO's National Environmental Sector on their support, revision and

365 constructive criticism. Opinions expressed here do not necessarily reflect current Civil Aviation

366 National Agency (ANAC) of Brazil's policy governing the control of wildlife near airports. In

367 Memorium: we dedicate this paper to the vivid memory of our beloved friend, avian ecologist and

368 coauthor, Rafael Guerta, who tragically passed away recently - a heartbreaking loss to us all.

369 He leaves much fine work unfinished and a trail of profound desolation.

370

371

372 References

373 AAA. 2016. Australian Airports Association. Wildlife hazard management at airports: airport 374 practice. Airport Practice: 9. West Burleigh: Avisure.

375

376 Allan JR. 2000. Bird strikes as a hazard to aircraft: a changing but predictable and manageable 377 threat. United Kingdom: Central Science Laboratory.

378 
379 Allan JR. 2002. The costs of bird strikes and bird strike prevention. In: Clark L, Hone J, Shivik

380 JA, Watkins RA, Vercauteren KC, Yoder JK, ed. Human conflicts with wildlife: economic 381 considerations. Proceedings of the Third NWRC Symposium. USA: Colorado. pp. 147-155.

382

383 ANAC. 2014. Agencia Nacional de Aviação Civil. Regulamento Brasileiro de Aviação Civil:

384 Gerenciamento do risco da fauna nos aeródromos públicos. № 164. Brasília.

385

386

Araujo GM, Terán AF, Guerta RS. 2015. Palestras de Educação Ambiental como Instrumento de 387

Prevenção de Acidentes em Operações Aeroportuárias. Educação Ambiental em Ação 53:1-7.

388

389

Avery ML, Humphrey JS, Daughtery TS, Fischer JW, Milleson MP, Tillman EA, Bruce WE, 390

Walter WD. 2011. Vulture flight behavior and implications for aircraft safety. Journal of Wildlife 391 Management 75:1581-1587.

392

393

Bastos, LCM. 2000. Brazilian Avian Hazard Control Program - Educational Initiatives. 394 International Bird Strike Committee:383-400. Holland: Amsterdam.

395

396

Bernhardt GE, Patton ZJ, Kutschbach-Brohl LA, Dolbeer RA. 2009. Management of bayberry in 397 relation to tree-swallow strikes at John F. Kennedy International Airport, New York. Human398 Wildlife Conflicts 3(2):237-241.

Blackwell BF, DeVault TL, Fernández-Juricic E, Dolbeer RA. 2009. Wildlife collisions with 401 aircraft: a missing component of land-use planning on and near airports Landscape and Urban 402 Planning 93:1-9.

403

404

BRASIL. 2012. Lei n ${ }^{\circ}$ 12.725, de 16 de outubro de 2012. Diário Oficial da República Federativa 405 do Brasil, 17 Outober 2012. Brasília:DF.

Breheny P, Burchett W. 2017. Visualizing regression models using visreg. Avaliable at: 408 http://myweb.uiowa.edu/pbreheny/publications/visreg.pdf(accessed 25 February 2018). 
410 Burnham KP, Anderson DR. 2002. Model selection and multimodel inference: a practical 411 information-theoretic approach. Second edition. New York: SpringerVerlag.

412

413 CENIPA 2016. Aeronautical Accidents Investigation and Prevention Center. Wildlife Strike Risk 414 Advisory. Ranking Brasileiro de Severidade Relativa de Espécies de Fauna. Brasília: DF. 415 Available at http://www2.fab.mil.br/cenipa/images/Anexos/Ranking_Risco_da_Fauna.pdf 416 (accessed 25 February 2018).

417

418 CENIPA 2017. Aeronautical Accidents Investigation and Prevention Center. Brazilian Bird Strike

419 Database. Available at http://www.cenipa.aer.mil.br/cenipa/sigra/pesquisa_dadosExt (accessed 42025 February 2018).

421

422 Cleary EC, Dolbeer RA, Wright SE. 2005. Wildlife strikes to civil aircraft in the United States, 423 1990-2004. Federal Aviation Administration, Serial Report No 11.Washington: USA.

424

425 Coleman JS, Fraser JD. 1989. Habitat use and home ranges of Black and Turkey vultures. Journal 426 of Wildlife Management 53:782-792.

427

DeVault TL, Beasley JC, Olson ZH, Moleón M, Carrete M, Margalida A, Antonio J. 2016. Ecosystem services provided by avian scavengers. In: Şekercioğlu ÇH, Wenny DG, Whelan CJ, 430 ed. Why birds matter: avian ecological function and ecosystem services. Chicago: University of 431 Chicago Press, 235-270.

432

433

DeVault TL, Belant JL, Blackwell BF, Seamans TW. 2011. Interspecific variation in wildlife 434 hazards to aircraft: implications for airport wildlife management. Wildlife Society Bulletin 35: 394435402.

436

437 DeVault TL, Kubel JE, Rhodes Jr OE, Dolbeer RA. 2009. Habitat and bird communities at small 438 airports in the midwestern USA. Proceedings of the Wildlife Damage Management Conference 439 13:137-145. 
441 DeVault TL, Reinhart BD, Brisbin Jr IL, Rhodes Jr OE. 2005. Flight behavior of black and turkey 442 vultures: implications for reducing bird-aircraft collisions. Journal of Wildlife Management 443 69:601-608.

445 Dolbeer RA, Eschenfelder P. 2003. Amplified bird-strike risks related to population increases of 446 large birds in North America. Proceedings of the 26th International Bird Strike Committee 447 Meeting 1:49-67.

Dolbeer RA, Seubert JL. 2009. Canada goose populations and strikes with civil aircraft, 1990450 2008: challenging trends for aviation industry. Special Report. U.S. Department of Agriculture,

Wildlife Services, Airport Wildlife Hazards Program, Washington: USA.

452

Dolbeer RA, Weller J, Anderson AL, Begier MJ. 2016. Wildlife strikes to civil aircraft in the 454 United States, 1990-2015. Federal Aviation Administration, Serial Report No. 22. Washington: 455 USA.

Dolbeer RA, Wright SE, Cleary EC. 2000. Ranking the hazard level of wildlife species to 458 aviation. Wildlife Society Bulletin 28: 372-378.

459

460

Dolbeer RA, Wright SE. 2008. Wildlife strikes to civil aircraft in the United States 1990-2007.

461 Other Bird Strike and Aviation Materials. Paper 24. Federal Aviation Administration. Serial 462 Report $N^{\circ} 14$. Washington: USA.

463

464 Dolbeer RA. 2006. Height distribution of birds recorded by collisions with civil aircraft. Journal 465 of Wildlife Management 70: 1345-1350.

466

467 Dolbeer RA. 2011. Increasing trend of damaging bird strikes with aircraft outside the airport 468 boundary: implications for mitigation measures. Human-Wildlife Interactions 5: 235-248. 
470 Freire DA, Gomes FBR, Cintra R, Novaes WG. 2015. Use of thermal power plants by new world 471 vultures (Cathartidae) as an artifice to gain lift. Wilson Journal of Ornithology 127:119-123.

472

473 Houston DC. 1986. Scavenging Efficiency of Turkey Vultures in Tropical forest. The condor $474 \quad 88: 319-323$.

475

476

477

IBGE. 2017. Brazilian Institute of Geography and Statistics: Cidades. Available at https://cidades.ibge.gov.br (accessed 25 February 2018).

478

Jones MR. 2005. Status and distribution of Black Vulture in Arizona, with notes on bird finding. 480 Arizona Birds Online 1(2):11-14.

481

482 Lisney TJ, Stecyk K, Kolominsky J, Graves GR, Wylie DR, Iwaniuk AN. 2013. Comparison of 483 eye morphology and retinal topography in two species of new world vultures (Aves: Cathartidae). 484 The Anatomical Record 296:1954-1970.

485

486 Loureiro K, Carlos CJ, Lamberts R. 2001. Estudo de estratégias bioclimáticas para a cidade de 487 Manaus. Encontro Nacional de Tecnologia do Ambiente Construído, Foz do Iguaçu: Brazil. 488

Martin JA, Belant JL, DeVault TL, Blackwell, BF, Burger Jr. LW, Riffell SK, Wang G. 2011. Wildlife risk to aviation: a multi-scale issue requires a multi-scale solution. Human-Wildlife 491 Interactions 5(2): 198-203.

492

Mendonça FAC. 2009. Gerenciamento do Perigo Aviário em Aeroportos. Conexão Sipaer 494 1(1):153-174.

495

Moore M, Gould P, Keary BS. 2003. Global urbanization and impact on health. International 497 Journal of Hygiene and Environmental Health 206: 269-278.

498

Nakagawa S, Schielzeth H. 2013. A general and simple method for obtaining $R^{2}$ from generalized 500 linear mixed-effects models. Methods in Ecology and Evolution 4: 133-142. 
501

502 Novaes WG, Alvarez MRDV. 2014. Relação entre resíduo solido urbano e urubu-de-cabeça-preta 503 (Coragyps atratus): Um perigo para as aeronaves no aeroporto de Ilhéus (SBIL). Conexão Sipaer 504 5: 22-29.

505

506 Novaes WG, Cintra R. 2013. Factors influencing the selection of communal roost sites by the 507 Black Vulture Coragyps atratus (Aves: Cathartidae) in an urban area in Central Amazon. Zoologia 508 30: 607-614.

509

510 Novaes WG, Cintra R. 2015. Anthropogenic features influencing occurrence of Black Vultures

511 (Coragyps atratus) and Turkey Vultures (Cathartes aura) in a urban area in central Amazonian

512 Brazil. The Condor: ornithological applications 117: 650-659.

513

514 Novaes, WG, Alvarez MRDV. 2010. O perigo aviário em aeroportos do nordeste do Brasil: análise 515 das colisões entre aves e aviões entre os anos de 1985 e 2009. Conexão Sipaer 1:47-68.

516

517 Oliveira BRH. 2012. Risco aviário e resíduo sólido urbano: A evolução, a realidade nacional e a 518 responsabilidade do poder público na prevenção de acidentes aeronáuticos [abstract $n^{\circ} 1096$ ]. 519 Anais do $5^{\circ}$ Simpósio de Segurança de Voo.

520

521 Parmalee PW. 1954. The vultures, their movements, economic status, and control in Texas. Auk $522 \quad 71: 443-453$.

523

524 Penrose K, Castro MCD, Werema J, Ryan ET. 2010. Informal urban settlements and cholera risk 525 in Dar es Salaam, Tanzania. PLoS Negleted Tropical Diseases 4(3):e631. DOI: 526 10.1371/journal.pntd.0000631.

527

528 R Development Core Team. 2018. R: A language and environment for statistical computing. R 529 Foundation for Statistical Computing. Available at http://www.R-project.org/ (accessed 25 530 February 2018). 
532 Richardson WJ, West T. 2000. Serious bird strike accidents to military aircraft: updated list and 533 summary. [abstract $\mathrm{n}^{0} 25$ ]. Proceedings of 25th International Bird Strike Committee Meeting (1): $534 \quad 67-98$.

535

536 Serrano IL, Neto AS, Alves VS, Maia M, Efe MA, Telino Jr WR, Amaral MF. 2005. Diagnóstico 537 da situação nacional de colisões de aves com aeronaves. Ornithologia 1:93-104.

538 Sick H. 1997. Ornitologia Brasileira. Rio de Janeiro: Editora Nova Fronteira.

539

540 SUBSEMPAB. 2018. State Secretariat for Trade and Markets. Available at 541 http://subsempab.manaus.am.gov.br/feiras/ (accessed 14 June 2018).

542

543 Thorpe J. 2003. Fatalities and destroyed aircraft due to bird strikes, 1912-2002. [abstract WP544 SA1]. Proceedings of the 26th International Bird Strike Committee Meeting 1:1912-2002. 545 Warsaw, Poland.

546

547 Thorpe J. 2005. Fatalities and destroyed aircraft due to bird strikes, 2002-2004. [abstract WPII548 3]. Proceedings of the 27th International Bird Strike Committee Meeting 1:17-24. Athens, Greece. 549

550 Thorpe J. 2016. Conflict of wings: birds versus aircraft. In: Angelici FM, ed. Problematic wildlife: 551 A cross-disciplinary approach. London: Springer, 443-463. 


\section{Table $\mathbf{1}$ (on next page)}

Name, size and geographic coordinates of street markets monitored in Manaus, Brazil. Name, size (in terms of the number of vendor stalls) and geographic coordinates of street markets monitored in Manaus, Brazil, and the type of rubbish bin (whenever available) and the corresponding Black Vulture abundance. 


\begin{tabular}{|c|c|c|c|c|c|c|}
\hline \multirow{2}{*}{ Street Market } & \multirow{2}{*}{$\begin{array}{l}\text { Geographic } \\
\text { Coordinates }\end{array}$} & \multirow{2}{*}{$\begin{array}{c}\text { Market } \\
\text { Size }\end{array}$} & \multirow{2}{*}{$\begin{array}{c}\text { Rubbish } \\
\text { Bin }\end{array}$} & \multicolumn{2}{|c|}{ Behavior } & \multirow{2}{*}{$\begin{array}{c}\text { Total } \\
\text { Abundance }\end{array}$} \\
\hline & & & & Flying & Grounded & \\
\hline $\begin{array}{l}\text { Feira do Bairro da } \\
\text { Paz }\end{array}$ & $\begin{array}{l}3^{\circ} 3 ' 24.72 " \mathrm{~S} \\
60^{\circ} 1 ' 56.63 " \mathrm{~W}\end{array}$ & 5 & $\begin{array}{l}\text { Small } \\
\text { House }\end{array}$ & 0 & 0 & 0 \\
\hline Feira João Sena & $\begin{array}{l}3^{\circ} 4^{\prime} 37.33^{\prime \prime S} \\
60^{\circ} 2^{\prime} 18.35^{\prime \prime} \mathrm{W}\end{array}$ & 21 & Absent & 0 & 0 & 0 \\
\hline Feira Dorval Porto & $\begin{array}{l}3^{\circ} 6^{\prime} 47.46^{\prime \prime} \mathrm{S} \\
60^{\circ} 1^{\prime} 24.77^{\prime \prime} \mathrm{W}\end{array}$ & 8 & Absent & 0 & 0 & 0 \\
\hline $\begin{array}{l}\text { Mercado Senador } \\
\text { Cunha Melo }\end{array}$ & $\begin{array}{l}3^{\circ} 7^{\prime} 20.99 " \mathrm{~S} \\
60^{\circ} 1^{\prime} 35.40^{\prime \prime} \mathrm{W}\end{array}$ & 20 & Absent & 0 & 0 & 0 \\
\hline $\begin{array}{l}\text { Feira da Manaus } \\
\text { Moderna }\end{array}$ & $\begin{array}{l}3^{\circ} 8^{\prime} 29.05^{\prime \prime} \mathrm{S} \\
60^{\circ} 1^{\prime} 19.91 " \mathrm{~W}\end{array}$ & 137 & Absent & 78 & 82 & 160 \\
\hline Feira da Panair & $\begin{array}{l}3^{\circ} 8^{\prime} 45.43 " \mathrm{~S} \\
60^{\circ} 0^{\prime} 37.88^{\prime \prime} \mathrm{W}\end{array}$ & 137 & Container & 445 & 365 & 810 \\
\hline $\begin{array}{l}\text { Mercado do Walter } \\
\text { Rayol }\end{array}$ & $\begin{array}{c}3^{\circ} 8^{\prime} 4.86^{\prime \prime S} \\
60^{\circ} 0^{\prime} 32.34^{\prime \prime} \mathrm{W}\end{array}$ & 38 & Container & 23 & 5 & 28 \\
\hline $\begin{array}{l}\text { Mercado } \\
\text { Maximinio Correa }\end{array}$ & $\begin{array}{l}3^{\circ} 7^{\prime} 13.79^{\prime \prime} \mathrm{S} \\
60^{\circ} 0^{\prime} 54.86^{\prime \prime} \mathrm{W}\end{array}$ & 3 & Absent & 0 & 0 & 0 \\
\hline $\begin{array}{l}\text { Feira do Porto da } \\
\text { Ceasa }\end{array}$ & $\begin{array}{c}3^{\circ} 8^{\prime} 3.10^{\prime \prime} \mathrm{S} \\
59^{\circ} 56^{\prime} 26.07^{\prime \prime} \mathrm{W}\end{array}$ & 21 & Container & 0 & 186 & 186 \\
\hline Feira do Japiim & $\begin{array}{c}3^{\circ} 6^{\prime} 44.19^{\prime \prime} \mathrm{S} \\
59^{\circ} 58^{\prime} 52.70^{\prime \prime} \mathrm{W}\end{array}$ & 9 & Absent & 0 & 0 & 0 \\
\hline $\begin{array}{l}\text { Feira Santo } \\
\text { Antônio }\end{array}$ & $\begin{array}{c}3^{\circ} 7^{\prime} 11.92^{\prime \prime} \mathrm{S} \\
60^{\circ} 2^{\prime} 39.17^{\prime \prime} \mathrm{W}\end{array}$ & 19 & Container & 0 & 31 & 31 \\
\hline Feira da Compensa & $\begin{array}{l}3^{\circ} 6^{\prime} 27.24 " \mathrm{~S} \\
60^{\circ} 3^{\prime} 18.58^{\prime \prime} \mathrm{W}\end{array}$ & 40 & Container & 35 & 192 & 227 \\
\hline Feira da Raiz & $\begin{array}{c}3^{\circ} 7^{\prime} 27.72^{\prime \prime} \mathrm{S} ; \\
59^{\circ} 59^{\prime} 42.40^{\prime \prime} \mathrm{W}\end{array}$ & 5 & Container & 0 & 0 & 0 \\
\hline Feira do Coroado & $\begin{array}{c}3^{\circ} 5^{\prime} 2.33 " \mathrm{~S} \\
59^{\circ} 58^{\prime} 48.71 " \mathrm{~W}\end{array}$ & 7 & Container & 0 & 116 & 116 \\
\hline $\begin{array}{l}\text { Feira da Armando } \\
\text { Mendes }\end{array}$ & $\begin{array}{c}3^{\circ} 5^{\prime} 24.78^{\prime \prime S} \\
59^{\circ} 56^{\prime} 35.55^{\prime \prime} \mathrm{W}\end{array}$ & 20 & $\begin{array}{c}\text { Small } \\
\text { House }\end{array}$ & 0 & 0 & 0 \\
\hline Feira do Mutirão & $\begin{array}{c}3^{\circ} 2^{\prime} 44.91 " \mathrm{~S} ; \\
59^{\circ} 56^{\prime} 36.58^{\prime \prime} \mathrm{W}\end{array}$ & 46 & Absent & 53 & 250 & 303 \\
\hline Feira do Produtor & $\begin{array}{c}3^{\circ} 2^{\prime} 11.32^{\prime \prime S} \\
59^{\circ} 56^{\prime} 26.66^{\prime \prime} \mathrm{W}\end{array}$ & 14 & Container & 0 & 0 & 0 \\
\hline $\begin{array}{l}\text { Feira da Cidade } \\
\text { Nova }\end{array}$ & $\begin{array}{c}3^{\circ} 1^{\prime} 53.62^{\prime \prime} \mathrm{S} \\
59^{\circ} 59^{\prime} 5.64^{\prime \prime} \mathrm{W}\end{array}$ & 10 & Container & 44 & 106 & 150 \\
\hline $\begin{array}{l}\text { Feira da Nova } \\
\text { Cidade }\end{array}$ & $\begin{array}{c}3^{\circ} 0^{\prime} 17.29^{\prime \prime} \mathrm{S} \\
59^{\circ} 58^{\prime} 32.69^{\prime \prime} \mathrm{W}\end{array}$ & 3 & Container & 0 & 1 & 1 \\
\hline $\begin{array}{l}\text { Feira do Mundo } \\
\text { Novo }\end{array}$ & $\begin{array}{c}3^{\circ} 2^{\prime} 23.31^{\prime \prime S} \\
59^{\circ} 59^{\prime} 53.93^{\prime \prime} \mathrm{W}\end{array}$ & 10 & Absent & 0 & 0 & 0 \\
\hline
\end{tabular}
1 


\section{Table 2 (on next page)}

Summary of the generalized-linear mixed models results of Black Vultures abundance related to presence or absence of rubbish bins, proportion of animal protein and market size.

Marginal $R^{2}$ values account for the variance explained by fixed variable only, while conditional $\mathrm{R}^{2}$ values represent the variance explained by both, fixed and the random factor. Market were declared as random factor in all models. 
1

\begin{tabular}{|c|c|c|c|c|c|}
\hline Dependent variable & $\begin{array}{l}\mathrm{R}^{2} \\
\text { marginal }\end{array}$ & $\begin{array}{l}\mathrm{R}^{2} \\
\text { conditional }\end{array}$ & Fixed factor & $b$ & $P$-value \\
\hline \multirow{3}{*}{$\begin{array}{l}\text { Total vulture } \\
\text { abundance }\end{array}$} & 0.628 & 0.879 & Presence or absence of rubbish bins & 2.162 & 0.006 \\
\hline & & & Proportion of animal protein & 2.296 & 0.005 \\
\hline & & & Market size & 1.152 & 0.116 \\
\hline \multirow{3}{*}{$\begin{array}{l}\text { Vulture abundance on } \\
\text { the ground }\end{array}$} & 0.644 & 0.877 & Presence or absence of rubbish bins & 1.986 & 0.018 \\
\hline & & & Proportion of animal protein & 2.890 & 0.001 \\
\hline & & & Market size & 0.781 & 0.290 \\
\hline \multirow{3}{*}{$\begin{array}{l}\text { Abundance of vultures } \\
\text { in flight }\end{array}$} & 0.162 & 0.162 & Presence or absence of rubbish bins & 1.103 & 0.391 \\
\hline & & & Proportion of animal protein & 1.460 & 0.319 \\
\hline & & & Market size & 2.727 & 0.051 \\
\hline
\end{tabular}

2 


\section{Table 3(on next page)}

Number of collisions, aircraft movements and collision index in different years for the two main airports in the city of Manaus, Brazil.

Number of collisions, aircraft movements and collision index (number of collisions per 10,000

flights) in different years for the two main airports in the city of Manaus. Flight movement data from the Flores Airport was unavailable. 


\begin{tabular}{ccccc}
\hline Airport & Year & Number of Collisions & Flights & Collision Index \\
\hline Eduardo Gomes (SBEG) & 2013 & 42 & 51234 & 8.2 \\
& 2014 & 26 & 53752 & 4.84 \\
& 2015 & 17 & 37782 & 4.5 \\
\hline Ponta Pelada (SBMN) & 2013 & 3 & 5702 & 5.26 \\
& 2014 & 4 & 5342 & 7.49 \\
& 2015 & 9 & 4411 & 20.4 \\
\hline
\end{tabular}

1

2

3 


\section{Figure 1}

Types of rubbish bins normally present in street markets in Manaus, Brazil.

(A) "Small house" rubbish bin without doors at Armando Mendes street market. (B) Closed

"small house" rubbish bin at Bairro da Paz street market. (C) "Container" rubbish bin at Ceasa

street market. (D) "Container" rubbish bin at Compensa street market. (E) "Container" rubbish bin at Coroado market. (F) "Container" rubbish bin at Feira do Produtor street market. Photo credit: Giase M. de Araújo. 

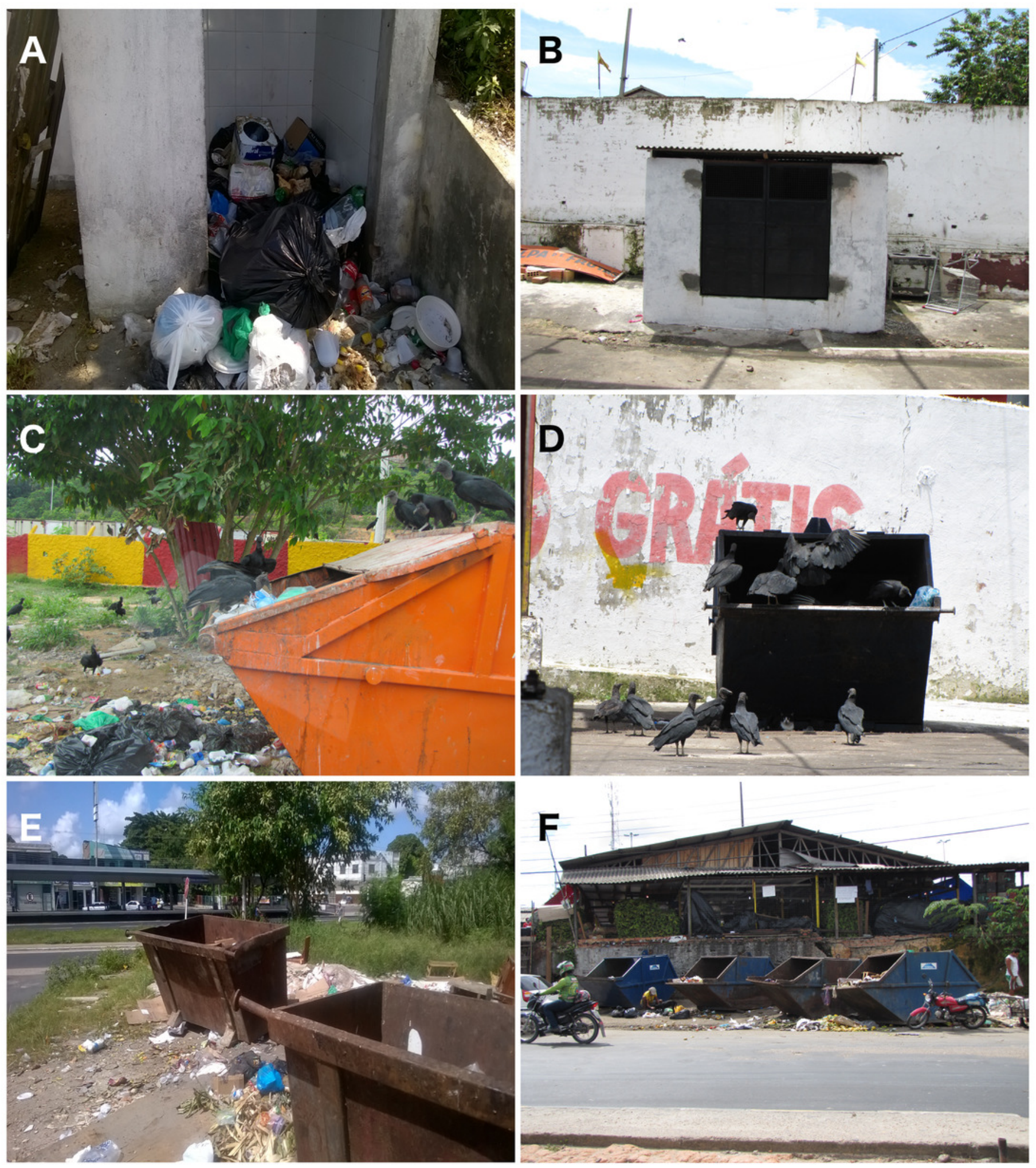


\section{Figure 2}

Map of the Manaus metropolitan area and the street markets surveyed in this study Map of the Manaus metropolitan area and the street markets surveyed in this study. Red circles and blue squares represent street markets where vultures were present or absent, respectively. Red circle sizes are proportional to the local abundance of vultures recorded at each street market. Bold straight lines indicate the runway location of the two main airports in Manaus: Eduardo Gomes International Airport of Manaus (SBEG) and Ponta Pelada Air Force Base (SBMN). White arrows show the main aircraft paths for either take-off or approach according to aeronautical charts. Image credit: Google, TerraMetrics, 2018. 


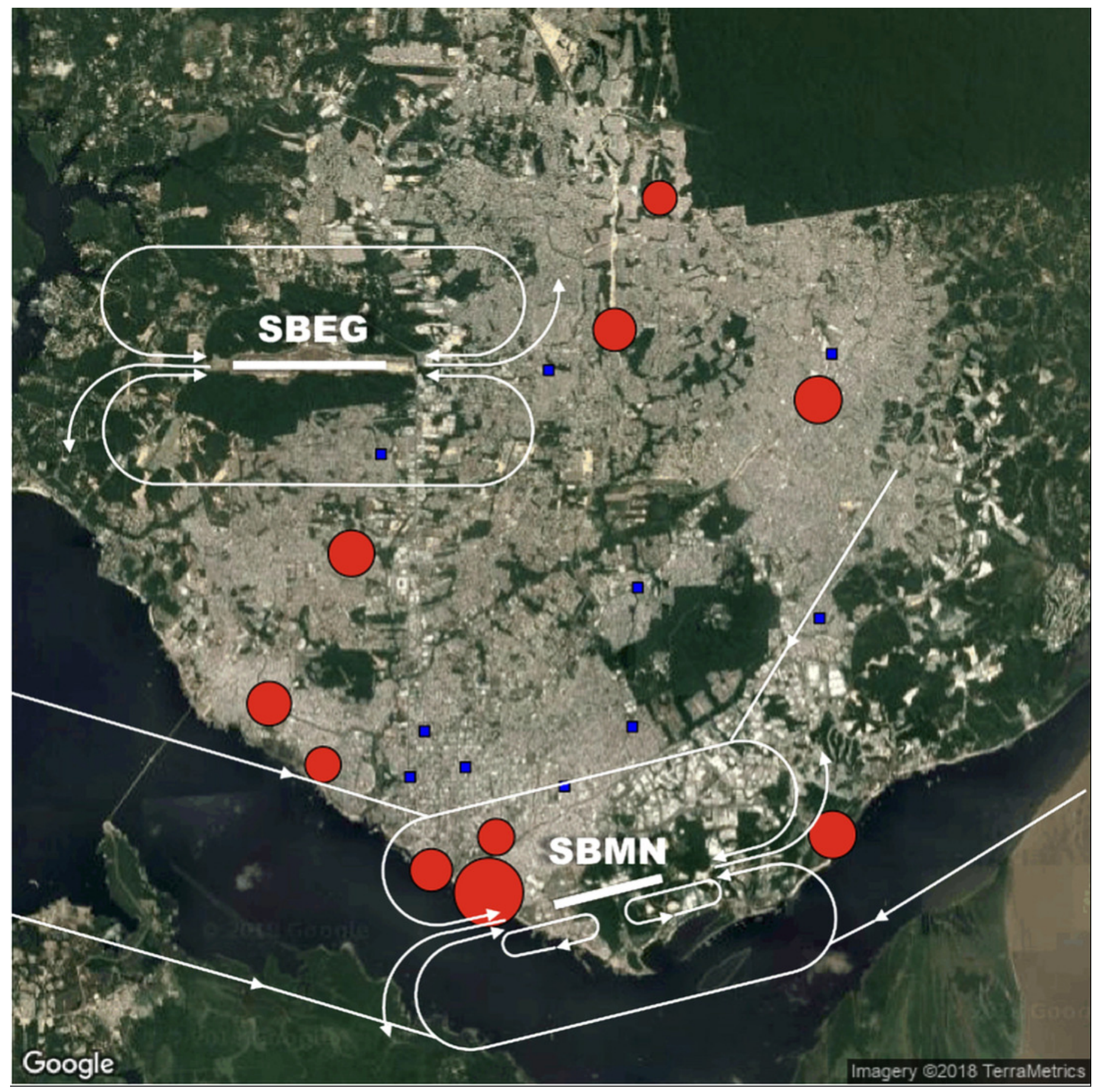




\section{Figure 3}

Partial residual plots of the effects of the proportion of animal protein contained in discarded organic solid waste for each street market on number of vultures recorded at each survey.

Partial residual plots of the effects of the proportion of animal protein (red meat or fish) contained in discarded organic solid waste for each street market, where rubbish containers were either present (green circles, and green $95 \% \mathrm{Cl}$ region) or absent (red circles, and red $95 \% \mathrm{Cl}$ region) on total number of vultures $(A)$ and number of vulture at the ground (B) recorded at each survey. The effects of market size (non-significant) and market identity (random variables) were both held constant.
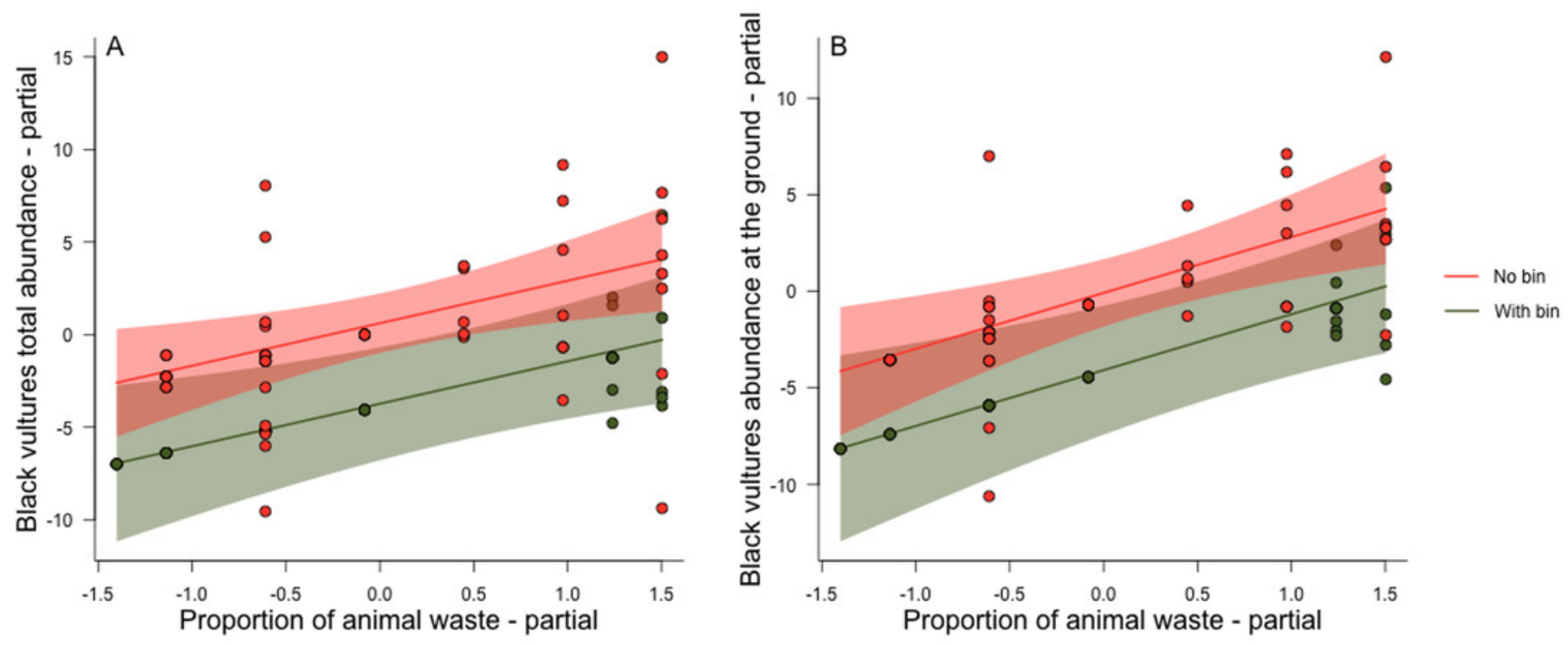


\section{Figure 4}

Mean number of Black Vultures in each urban market surveyed.

Mean number of Black Vultures represented by horizontal bars in each urban market surveyed. Horizontal lines represents the standard deviation of Black Vultures abundance of each market. The color gradient represents the composite index (DI) of distance to the nearest airport created by dividing the airport size (mean number of aircraft flights per year) by the square-root of the linear (vulture flight) distance from each market to that airport.

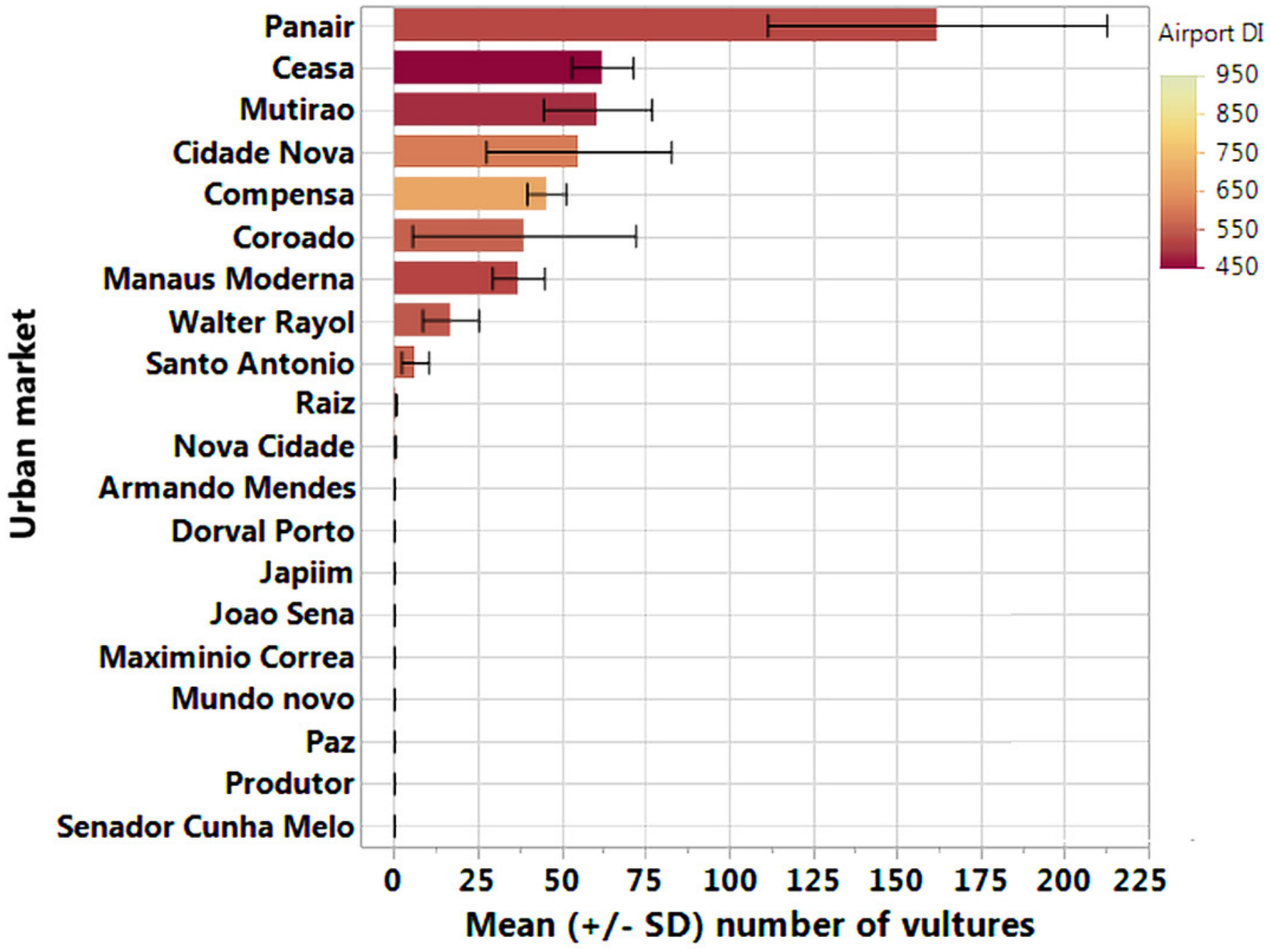

